DOI: $10.19195 / 2300-7729.37 .2$

\title{
Biblioteki dwudziestolecia międzywojennego na łamach „Przeglądu Księgarskiego"
}

W historii bibliotekarstwa polskiego dwudziestolecie międzywojenne postrzegane jest jako okres rozwoju i zmian. Przed bibliotekami w niepodległej Polsce stanęły nowe wyzwania i funkcje do spełnienia. Znaczące przedsięwzięcia - jak powołanie Biblioteki Narodowej, tworzenie prawa bibliotecznego, kwestie kształcenia bibliotekarzy — przeplatały się z codziennością bibliotek oświatowych i szkolnych (między innymi problemami dotyczącymi gromadzenia zbiorów, lokalu, personelu). Artykuł jest próbą przedstawienia sposobu, w jaki księgarze postrzegali biblioteki i ich funkcje oraz zasady współpracy na rynku książki w okresie dwudziestolecia międzywojennego.

Temat został opracowany w oparciu o analizę zawartości „Przeglądu Księgarskiego" - pisma będącego organem prasowym Związku Księgarzy Polskich $(\mathrm{ZKP})^{1}$. Badaniami objęto wybrane roczniki, dobrane tak, aby zaprezentować

1 „Przegląd Księgarski” zaczął ukazywać się w 1910 roku jako organ Związku Księgarzy Polskich w Królestwie Polskim. Miesięcznik był wydawany do 1914 roku i został wznowiony w marcu 1918 roku. Od 1 października 1918 roku pismo funkcjonowało jako „organ Związku Powszechnego Księgarzy Polskich”, a redaktorem został Mieczysław Rulikowski. W lutym 1919 roku zastąpił go Stanisław Lam, który sprawował tę funkcję do lutego 1920 roku. W ciągu roku wyszedł jeden podwójny numer i wydawanie pisma zawieszono. Po przerwie pierwszy numer miesięcznika — „organu Związku Powszechnego Księgarzy i Wydawców Polskich” ukazał się w 1922 roku pod redakcją Adama Szymańskiego. Od 1925 roku „Przegląd Księgarski” zaczął wychodzić jako dwutygodnik, a od października tegoż roku do końca 1929 roku ukazywał się już jako tygodnik. W 1930 roku redakcję przejął Jan Muszkowski. Po podpisanym w 1932 roku porozumieniu ZKP i Polskiego Towarzystwa Wydawców Książek „Przegląd” stał się „organem Zjednoczonych Organizacji Księgarskich PTWK i ZKP”. Efektem wprowadzanych wówczas oszczędności było odejście J. Muszkowskiego i przekazanie redakcji kolejnym dyrektorom Biura ZOK. „Przegląd” zaczął pełnić funkcję biuletynu informacyjnego. Od lipca 1935 roku dwutygodnik ponownie został organem ZKP. Wrócił także na swoje dawne stanowisko Adam Szymański, piastując je do końca 1939 roku. Od 1 stycznia 1939 roku „Przegląd” zaczął ukazywać się 
problem na przestrzeni całego omawianego okresu: 1918/1919-1920, 1922-1928, 1935-1939. Zrezygnowano z przeprowadzania szczegółowej analizy ilościowej, ograniczając ją do wyrywkowych danych opartych na bibliografii zawartości pi$\mathrm{sma}^{2}$. Postanowiono skupić się na treści publikowanych materiałów. Szczegółowo opisano najbardziej charakterystyczną problematykę zajmującą środowisko księgarskie.

Przeanalizowano łącznie trzysta osiemdziesiąt jeden tekstów o różnej objętości. W poszczególnych rocznikach liczba tekstów o bibliotekach wahała się od jednego w 1920 roku do osiemdziesięciu w 1928 roku$^{3}$. Wyraźnie widoczna była przewaga tekstów dotyczących bibliotek polskich - 66,4\%. Artykuły były głównie echem tego, co działo się w polskim bibliotekarstwie i miało związek z księgarstwem. W wypadku bibliotek zagranicznych było to 33,6\% tekstów, które traktowały głównie o bibliotekach prywatnych, publicznych oraz ustawach bibliotecznych.

Przeprowadzone badania wykazały szerokie spektrum poruszanej problematyki. W tekstach prezentowano między innymi ujęcia statystyczne - dotyczące księgozbiorów i czytelników; opisywano funkcje i zadania bibliotek różnego typu; podejmowano problematykę związaną z organizacją bibliotek i ich podstawowymi procesami, ze szczególnym uwzględnieniem polityki gromadzenia zbiorów i udostępniania. Zajmowano się również tak istotnymi kwestiami, jak idea biblioteki narodowej, egzemplarz obowiązkowy i podstawy prawne funkcjonowania bibliotek. Informowano także o działalności związkowej bibliotekarzy, kursach zawodowych i prasie bibliotekarskiej.

Na potrzeby analizy teksty pogrupowano tematycznie: biblioteki różnego typu - szkolne $\left(34-8,92 \%{ }^{4}\right)$, publiczne $(40-10,49 \%)$, narodowe $(19-$ $4,98 \%)$, dla dzieci i młodzieży $(12-3,14 \%)$, związane z instytucjami religijnymi - klasztorne, parafialne, watykańska $(10-2,62 \%)$, instytucji $(22-5,77 \%)$,

trzy razy w miesiącu. W latach 1918-1939 wydano dwadzieścia roczników pisma, różniących się częstotliwością ukazywania, objętością i formatem. Pismo wydawano w nakładzie od 1200 do 2000 egzemplarzy. Szerzej zob. R. Salinger, „Przegląd Księgarski” w latach 1918-1939, „Księgarz” 1971, nr 3, s. 44-54. Stan badań nad „Przeglądem Księgarskim” zob. m.in. M. Olczak-Kardas, Przedmowa, [w:] eadem, „Przeglad Księgarski”. Adnotowana bibliografia zawartości za lata 1918-1939, t. 1. 1918-1925, Kielce 2016, s. 8-15.

2 M. Olczak-Kardas, „Przegląd Księgarski”. Adnotowana bibliografia zawartości za lata 1918-1939, t. 1. 1918-1925, Kielce 2016; t. 2. 1926-1928, Kielce 2017.

${ }^{3}$ Liczba tekstów o bibliotekach w pozostałych rocznikach: 1918/1919 - 10, $1922-11$, $1923-11,1924-12,1925-25,1926-48,1927-71,1935-15,1936-35,1937-14$, 1938 - 21, 1939 - 27. Procentowo był to przedział od 2,1\% w roczniku 1918/1919 do 7,75\% w 1927 roku. Obliczenia procentowe dotyczą jedynie roczników za lata 1918-1928, dla których ukończono prace bibliograficzne. Udział procentowy tekstów o bibliotekach w pozostałych rocznikach: $1920-3,03 ; 1922-3,44 ; 1923-2,98 ; 1924-3,01 ; 1925-3,01 ; 1926-6,4 ; 1928-$ 5,57. Obliczenia własne.

${ }^{4}$ W nawiasach podano liczbę tekstów poruszających daną tematykę oraz wyliczenia procentowe. Niektóre teksty zostały przyporządkowane do kilku kategorii. Obliczenia własne. 
społeczne - towarzystw i organizacji $(10-2,62 \%)$, naukowe $(9-2,36 \%)$, uczelniane $(13-3,42 \%)$, prywatne $(30-7,87 \%)$, ruchome $(9-2,36 \%)$; ustawa biblioteczna (14 - 3,67\%); egzemplarz obowiązkowy $(6-1,57 \%)$; bibliotekarze (43 - 11,28\%); ogólna problematyka bibliotekarska $(110-28,87 \%)$.

Ze względu na istotę sezonu podręcznikowego oraz potrzebę zakładania i uzupełniania bibliotek szkolnych wiele tekstów związanych było z obecnością książki w szkole. „Przegląd Księgarski” poruszał różne aspekty tematu. Analizowane wzmianki dotyczyły przede wszystkim kwestii gromadzenia zbiorów (w tym: zakup, dary), propagowania czytelnictwa, podstaw prawnych funkcjonowania bibliotek — różnego rodzaju rozporządzeń ministerialnych (między innymi dotacji).

Firmy księgarskie wspomagały tworzenie bibliotek szkolnych między innymi w ramach fundacji. Już w roczniku 1918/1919 można spotkać informację o wielkości i wykorzystaniu księgozbioru dla szkół miejskich stworzonego z książek pochodzących z fundacji Michała Arcta ${ }^{5}$. W 1922 roku opisano dar dla biblioteki Państwowego Konserwatorium Muzycznego przekazany przez firmę Gebethner i Wolff ${ }^{6}$.

Na łamach pisma pojawiały się apele nowo powstających bibliotek szkolnych z prośbą o dary książkowe. Zamieszczano tego typu informacje, licząc na odzew księgarzy i wydawców ${ }^{7}$. Czasami na prośby bibliotek szkolnych odpowiadała sama redakcja „Przeglądu Księgarskiego”, wykazując tym samym pełne zrozumienie ich potrzeb oraz pełnionych funkcji. Przykładem może być przesłanie czterdziestu książek do bibliotek szkolnych Górnego Śląska. Redakcja przekazała publikacje, które otrzymywała w celach informacyjnych od wydawnictw. Powiadomiono o tym fakcie, publikując w 1923 roku podziękowania przesłane na adres redakcji ${ }^{8}$.

Najwięcej uwagi i emocji wśród księgarzy wzbudzała kwestia gromadzenia poprzez zakup w bibliotece szkolnej. Środowisko księgarskie bardzo szybko reagowało na wszelkie nieprawidłowości. W 1925 roku „Przegląd Księgarski” przedrukował artykuł z „Kuriera Poznańskiego” (z 12 grudnia 1924 roku). Tekst dotyczył pisma Ministerstwa Wyznań Religijnych i Oświecenia Publicznego (MWRiOP) z 21 listopada 1924 roku zawiadamiającego kuratoria okręgów szkolnych o przyznaniu ze swego budżetu dyrekcjom wszystkich państwowych szkół średnich ogólnokształcących po pięćset złotych na zakup książek do biblioteki zakładu. Zamówienia można było składać jedynie w Książnicy Polskiej Towarzystwa Nauczycieli Szkół Średnich i Wyższych w Warszawie. Komentarz dotyczył faktu, że Książnica była przedsiębiorstwem zarobkowym, którego udziały

5 Biblioteka Szkolna im. Michała Arcta przy PMS, „Przegląd Księgarski” 1918/1919, nr 2, s. 62 .

6 Hojny dar, „Przegląd Księgarski” 1922, nr 4 i 5, s. 98.

7 Zob. m.in. Biblioteka szkolna w Tczewie, „Przegląd Księgarski” 1922, nr 2, s. 42.

8 [Towarzystwo Opieki Kulturalnej nad Polakami Zamieszkałymi Zagranicą im. A. Mickiewicza], „Przegląd Księgarski” 1923, nr 12, s. 182-183. 
należały do nauczycieli i pracowników MWRiOP ${ }^{9}$. Domagano się w tej sprawie interpelacji poselskiej, uważając całą sprawę za skandal, a rzesze księgarzy za pokrzywdzonych. Zapowiadano podjęcie daleko idących działań w tej sprawie ${ }^{10}$.

Środowisko księgarskie reagowało na łamach pisma na nieprzemyślane decyzje ministerstwa, które narażały księgarzy i wydawców na dodatkowe koszty. W 1926 roku zajęto się między innymi decyzją o wstrzymaniu akcji organizowania bibliotek szkolnych. Księgarze i wydawcy ponieśli koszty, zwiększając produkcję literatury dziecięco-młodzieżowej, i w związku z tym apelowano do ministerstwa o pomoc kredytową na rozwój bibliotek szkolnych ${ }^{11}$. Kolejna niekorzystna decyzja ministerstwa związana była z przyznawaniem co pewien czas bibliotekom szkolnym kredytów w formie książek. Zgodnie z wytycznymi ministerialnymi należało je zakupić u wydawców, którzy mieli zastosować wobec szkół oryginalne rabaty księgarskie. Księgarze odebrali to rozwiązanie jako obciążające ich nowe świadczenie na rzecz państwa ${ }^{12}$.

Odrębną grupę tematyczną stanowiły reklamy wydawnictw przydatnych w organizowaniu i kompletowaniu bibliotek szkolnych. Były to zarówno publikacje ZKP, jak i innych wydawców. Prace niejednokrotnie dodawano bezpłatnie do „Przeglądu Księgarskiego" i rozsyłano między innymi do zarejestrowanych firm. Przykładem mogą być anonse dotyczące: Katalogu polskich bibliotek szkolnych wg tytułów (nakład Księgarnia Perzyński, Niklewicz i S-ka) ${ }^{13}$; publikacji Jadwigi Filipkowskej-Szemplińskiej i Marii Gutry, Katalog biblioteki wzorowej dla dzieci i młodzieży, z przedmową Heleny Radlińskiej, Warszawa 192714; H. Orszy, Zadania biblioteki szkolnej, Warszawa $1927^{15}$. Warto zwrócić uwagę na informację o publikacji Szkolne biblioteki dla mtodzieży. Instrukcja i katalog, Warszawa 1926 (wydana przez M. Arcta) oraz komentarz o małym zainteresowaniu wydawnictwem wśród nauczycieli: „To zniechęcenie i apatia, brak zainteresowania, jest spowodowane brakiem funduszów, uniemożliwiających szkołom dokonywanie jakichkolwiek zakupów dla bibliotek"16.

W wypadku bibliotek szkolnych na szczególną uwagę zasługuje akcja „Miesiąc książki dla młodzieży szkół powszechnych” organizowana w całym kraju, która miała propagować czytelnictwo i przyczynić się do rozwoju bibliotek szkol-

9 Czy nowy monopol?, „Przegląd Księgarski” 1925, nr 1, s. 9-10.

10 Wyjaśnienie, „Przegląd Księgarski” 1925, nr 3, s. 75.

11 Memoriał Związu Polskich Księgarzy Wydawców, złożony dn. 23 lutego 1926 r. Sejmowi w sprawie bibliotek szkolnych, „Przegląd Księgarski” 1926, nr 4-5, s. 85-86.

12 S. Kowalczyk, Nowy podatek, „Przegląd Księgarski” 1928, nr 6, s. 88-90.

13 Pożyteczne wydawnictwo, „Przegląd Księgarski” 1926, nr 9, s. 206. Uzupełnienia i kontynuacji katalogu podjął się ZKP. W 1927 roku opublikowano apel do firm o przesłanie wydawnictw nadających się do zamieszczenia w tym katalogu. Zob. Katalog polskich bibliotek szkolnych wg tytułów, „Przegląd Księgarski” 1927, nr 22, s. 464.

14 Katalog biblioteki wzorowej, „Przegląd Księgarski” 1927, nr 1, s. 2.

15 Zadania biblioteki szkolnej, „Przegląd Księgarski” 1927, nr 1, s. 2-3.

16 Szkolne biblioteki dla młodzieży, „Przegląd Księgarski” 1927, nr 1, s. 20. 
nych. „Miesiąc książki” został przedstawiony jako korzystny czas dla księgarń pod warunkiem, że księgarze zdołają go umiejętnie spożytkować. Inicjatywy ZKP, które omawiano na łamach pisma, to między innymi powołanie Komitetu Propagandy Czytelnictwa, publikacje ZKP związane z książką dla dzieci i młodzieży, konkurs wystaw okiennych. W większości tekstów apelowano do księgarzy o włączenie się do akcji propagowania książki z myślą o przyszłych klientach i zwiększeniu zakupów. Sporadycznie pojawiały się wzmianki o roli wychowawczej biblioteki szkolnej ${ }^{17}$.

W 1927 roku na łamach „Przeglądu Księgarskiego” opublikowano fragment okólnika MWRiOP z grudnia 1926 roku dotyczącego wspomnianej akcj1 ${ }^{18}$. Okólnik omawiał wiele kwestii: stan czytelnictwa młodzieży, liczbę bibliotek szkolnych, „Miesiąc książki dla młodzieży szkół powszechnych” (luty 1927), zakup książek. Redakcja przytoczyła w całości akapit dotyczący zakupu, którym księgarstwo było najbardziej zainteresowane. Ministerstwo za zasadę uznało niecentralizowanie zakupów. Ci, którzy zebrali fundusze - komitety, organizacje mieli prawo decydować, co, gdzie i dla jakiej biblioteki zostanie kupione. ZKP apelował, by księgarze weszli do lokalnych komitetów organizacyjnych tej akcji: „Akcja księgarzy powinna iść w tym kierunku, aby zapewnić dokonywanie przez Komitety zakupów na miejscu u siebie. Byłoby też pożądane tworzenie kompletów książek w cenie 100 zł, 50 zł, 25 zł i in." 19

Zarząd Główny ZKP wystosował w sprawie akcji okólnik, a jego odpis rozesłano do wszystkich firm zarejestrowanych w Związku ${ }^{20}$. Dotyczył między innymi uchwalenia jednorazowej daniny na rzecz propagandy „Miesiąca książki dla młodzieży szkół powszechnych”. ZG ZKP zwracał uwagę na duże koszty, jakie Związek będzie musiał ponieść. ZKP nie posiadał pieniędzy na sfinansowanie tego przedsięwzięcia, stąd podjęcie uchwały o jednorazowej daninie księgarskiej na koszty propagandy w wysokości 50\% składki (zastrzegano ewentualny wzrost do 100\%). Wyjaśnienie ZG ZKP odsłoniło przyświecające tej decyzji i podjętym działaniom powody:

Uchwała została powzięta w przekonaniu, że wyłożone przez księgarstwo na daninę kwoty zwrócą się z okładem, choćby dlatego, że jeśli 25.000 szkół powszechnych, które kraj posiada, zakupi w „Miesiącu książki” dla swych bibliotek książek choćby tylko za 20 zł każda, to ogólny rezultat dla księgarstwa wyrazi się w sumie $500.000 \mathrm{zł}^{21}$.

Liczono także na długofalowy efekt całej akcji i zwiększone działania rządu i instytucji samorządowych na rzecz tworzenia bibliotek i rozwijania czytelnic-

17 Zob. m.in. A.L. Szymański, Księgarstwo a miesiąc książki, „Przegląd Księgarski” 1927, nr 3, s. 62-63.

18 Miesiąc książki dla młodzieży szkół powszechnych, „Przegląd Księgarski” 1927, nr 1, s. 3-7.

19 Ibidem, s. 7.

20 Miesiąc książki dla młodzieży szkół powszechnych, „Przegląd Księgarski” 1927, nr 2, s. 32-33.

${ }^{21}$ Ibidem, s. 33. 
twa. Odzew na dodatkową opłatę był różny ${ }^{22}$. Wielu księgarzy twierdziło, że ze względu na kryzys nie wystarczało nawet na składki. Jednocześnie, mimo iż cały czas wiele osób bezinteresownie, z pobudek obywatelskich, brało udział w akcji propagowania czytelnictwa, dodatkowe fundusze były niezbędne: ,Jeżeli więc chcemy przyspieszenia nadejścia lepszych czasów dla całego księgarstwa, nie ociągajmy się ze złożeniem daniny, bo celowy wydatek zawsze się opłaci!...”23

„Przegląd Księgarski” publikował informacje o imprezach odbywających się na terenie kraju w ramach „Miesiąca książki”. Większość z nich była organizowana przez księgarzy w porozumieniu z nauczycielami. Opisywano formy propagandy, podawano uzyskane kwoty i informacje o zakupionych książkach do bibliotek szkolnych ${ }^{24}$.

Informowano na łamach pisma o wysokości dotacji ministerialnych przeznaczonych na powiększenie księgozbiorów bibliotek szkolnych (między innymi wyasygnowanie przez MWRiOP pięćdziesięciu tysięcy złotych na powiększenie bibliotek w szkołach średnich województw: poleskiego, poznańskiego, pomorskiego) ${ }^{25}$. Opisywano wymierne efekty, jakie akcja przyniosła księgarzom w Warszawie i na prowincji (między innymi zwiększone zamówienia od bibliotek szkolnych) ${ }^{26}$. W ramach akcji dotacje na biblioteki szkolne płynęły również od władz samorządowych, na przykład Sejmik Hrubieszowski przeznaczył na powiększenie bibliotek szkolnych dziesięć tysięcy złotych ${ }^{27}$. Na łamach pisma powiadamiano księgarzy o wszelkich dodatkowych inicjatywach władz lokalnych, na przykład przedłużeniu czasu trwania akcji, publikowaniu specjalnych list dla bibliotek szkolnych.

Książnice narodowe także zajmowały polskich księgarzy — zarówno zagraniczne, jak i inicjatywa powołania, a później funkcjonowania Biblioteki Narodowej w Warszawie. W wypadku zagranicznych książnic tematyka dotyczyła między innymi książki polskiej w zbiorach ${ }^{28}$, zbiorów bibliotecznych i ich gromadzenia (zakup wartościowych egzemplarzy, włączanie do zbiorów kolekcji prywatnych pochodzących od znanych osób, statystyk), działalności bibliograficznej i wydawniczej, czytelnictwa. Opisano między innymi Bibliotekę Narodową w Paryżu (głów-

${ }^{22}$ Nasza danina, „Przegląd Księgarski” 1927, nr 3, s. 64-65.

23 Ibidem, s. 65.

24 St.K., Echa „Miesiąca Książi”, ,Przegląd Księgarski” 1927, nr 6, s. 150-152; Akcja na rzecz czytelnictwa w Lodzi, „Przegląd Księgarski” 1927, nr 14, s. 343; Zakończenie działalności „Miesiąca książki” w Olkuszu, „Przegląd Księgarski” 1927, nr 23, s. 489-490; Sprawozdanie Koła Księgarzy Zagłębia Dąbrowskiego z „Miesiąca Książk”, „Przegląd Księgarski” 1927, nr 8-9, s. 219-220; Pokaz książki w Słonimie, „Przegląd Księgarski” 1927, nr 10, s. 265.

25 Echa „Miesiąca Książki”, „Przegląd Księgarski” 1927, nr 6, s. 132.

26 Ibidem.

27 Echa „Miesiąca książi”. Sejmik Hrubieszowski, „Przegląd Księgarski” 1927, nr 4, s. 75.

28 L. Morgiewicz, O książki polskie w paryskiej Bibliotece Narodowej, „Przegląd Księgarski” 1922, nr 3, s. 60. 
nie zbiory i lokal) ${ }^{29}$, Bibliotekę Muzeum Brytyjskiego w Londynie ${ }^{30}$, bibliotekę w Kopenhadze ${ }^{31}$, w Hiszpanii ${ }^{32}$, w Buenos Aires (książka mówiona) ${ }^{33}$, Narodową Bibliotekę Żydowską w Jerozolimie (działalność bibliograficzna i wydawnicza) ${ }^{34}$.

Teksty o bibliotece narodowej w Polsce poruszały następującą problematykę: projekt powołania biblioteki; zbiory — między innymi odzyskane; rozporządzenia dotyczące Biblioteki Narodowej; fundusze, budynek; struktura organizacyjna, w tym Instytut Bibliograficzny. Warto zwrócić uwagę na podjęcie tematu dotyczącego ogólnego braku wiedzy wśród społeczeństwa i księgarzy na temat powołania Biblioteki Narodowej ${ }^{35}$. Księgarski periodyk zajął się również kwestią współistnienia Biblioteki Jagiellońskiej i Biblioteki Narodowej w Warszawie. W tym wypadku redakcja nie zajęła konkretnego stanowiska, twierdząc, że problem wymaga zbadania ${ }^{36}$. W „Przeglądzie Księgarskim” przedrukowywano także artykuły z innych czasopism na temat Biblioteki Narodowej, między innymi Zuzanny Rabskiej („Kurier Warszawski” 15 kwietnia 1926 roku) — zakres pojęcia „biblioteka narodowa”, działania Stefana Dembego, opis zgromadzonego księgozbioru ${ }^{37}$; wywiad ze Stefanem Dembym („Kurier Czerwony” 12 marca 1928 roku) ${ }^{38}$; Jana Lorentowicza („Prawda” 22 kwietnia 1928) - między innymi zbiory, Instytut Bibliograficzny ${ }^{39}$.

Informacje o bibliotekach prywatnych dotyczyły bibliotek polskich i zagranicznych, z przewagą zagranicznych, w tym głównie amerykańskich. Przede wszystkim na łamach „Przeglądu Księgarskiego” pojawiały się opisy zasobów, sposobów tworzenia kolekcji ${ }^{40}$, omówienia ciekawych zbiorów prywatnych ${ }^{41}$. Opi-

2980 kilometrów książek, „Przegląd Księgarski” 1922, nr 3, s. 67; Rzadka książka, „Przegląd Księgarski” 1922, nr 12, s. 189; Największa biblioteka, „Przegląd Księgarski” 1924, nr 1-2, s. 15-16; Kolekcja „Kanonizacyj” w Bibliotece Narodowej Paryskiej, „Przegląd Księgarski” 1925, nr 1, s. 18-19; Największa biblioteka w świecie, „Przegląd Księgarski” 1927, nr 21, s. 460; Co posiada Biblioteka Narodowa w Paryżu, „Przegląd Księgarski” 1928, nr 6, s. 95.

30 Osiemdziesiąt kilom. książek, „Przegląd Księgarski” 1926, nr 20, s. 394; Biblioteka muzeum w Londynie, „Przegląd Księgarski” 1928, nr 1, s. 15.

31 Biblioteka Jerzego Brandes'a, „Przegląd Księgarski” 1928, nr 11, s. 175.

32 Książka w Hiszpanii, „Przegląd Księgarski” 1928, nr 22, s. 351.

33 F.B., Książki mówione, „Przegląd Księgarski” 1938, nr 20, s. 246.

34 Dziennikarstwo w Palestynie, ,Przegląd Księgarski” 1927, nr 2, s. 52.

35 St.Pl., W sprawie Biblioteki Narodowej, „Przegląd Księgarski” 1928, nr 14, s. 213-215.

36 St.Pl., Jedna czy dwie biblioteki narodowe?, „Przegląd Księgarski” 1928, nr 24, s. 380-381; Spór o „Bibliotekę Narodowa”, „Przegląd Księgarski” 1928, nr 30, s. 476-478.

37 [Projekt polskiej biblioteki narodowej], „Przegląd Księgarski” 1926, nr 8, s. 180-181.

38 Ustanowienie Biblioteki Narodowej, „Przegląd Księgarski” 1928, nr 13, s. 204-205.

39 Biblioteka Narodowa, „Przegląd Księgarski” 1928, nr 19, s. 296-297.

40 M.R., Biblioteka imienia Rylandsa (John Rylands Library) w Manczesterze, „Przegląd Księgarski” 1927, nr 2, s. 50-51.

${ }^{41}$ Książka z drzewa, „Przegląd Księgarski” 1927, nr 2, s. 5; Biblioteka książek miniaturowych, „Przegląd Księgarski” 1928, nr 32, s. 510-511; Odkrycie nieznanej biblioteki muzycznej, „Przegląd Księgarski” 1927, nr 5, s. 125-126; Największa biblioteka wojenna, „Przegląd Księgarski” 1928, nr 33, s. 524-525. 
sywano transakcje po śmierci właścicieli bibliotek w różnych krajach — Polska ${ }^{42}$, Stany Zjednoczone ${ }^{43}$, Belgia ${ }^{44}$, Francja ${ }^{45}$. Często w tekstach tematyka bibliotek prywatnych i publicznych łączyły się ze względu na przekazywanie w darze zbiorów prywatnych bibliotekom publicznym ${ }^{46}$, miastu ${ }^{47}$, stanowi ${ }^{48}$, uniwersyteto$\mathrm{wi}^{49}$. Informowano o ciekawostkach związanych z zawartością prywatnych zbiorów (unikatowe egzemplarze, ważne dokumenty) ${ }^{50}$. Poza tym podjęto następujące kwestie: politykę władz wobec prywatnych bibliotek i czytelni w Rosji ${ }^{51}$; rozproszenie kolekcji europejskich po wojnie ${ }^{52}$; zbiory prywatne księgarzy za granicą ${ }^{53}$; losy historycznych księgozbiorów prywatnych, między innymi Napoleona ${ }^{54}$.

$\mathrm{Na}$ łamach pisma pojawiła się także kwestia biblioteczek domowych. Temat ten podjął w swoim artykule ${ }^{55}$ między innymi Jakub Vorzimmer — znający realia rynku zarówno polskiego, jak i amerykańskiego. Tak jak każda amerykańska miejscowość posiadała swoją bibliotekę publiczną, tak w każdym amerykańskim domu musiała być biblioteczka domowa. Jej wielkość była uzależniona od zasobności domu, ale zawsze była chlubą gospodarzy: „w pojęciu Amerykanina brak biblioteki w domu byłby dowodem braku kultury amerykańskiej, dowodem złego smaku"56. Według autora w Polsce nie odczuwano takiej konieczności (wyjątek stanowiły biblioteki fachowe w wypadku niektórych zawodów).

Jak już wspomniano, w „Przeglądzie Księgarskim” przedrukowywano wiele artykułów z różnych codziennych gazet i tematycznych periodyków. W odniesieniu do bibliotek prywatnych warto zwrócić uwagę na tekst dotyczący biblioteki domowej pochodzący z „Wiadomości Literackich”57. Autor W. Grubiński udowadniał, że „Tylko głupcy nie posiadają biblioteki, w myśl starego Salomonowego orzeczenia, iż »nie przystoi rozkosz głupiemu«"58, a „Między rozkoszami tego

42 Biblioteka po W. Gomulickim, „Przegląd Księgarski” 1918/1919, nr 11-13, s. 240.

43 Póttora miliona dolarów za bibliotekę, „Przegląd Księgarski” 1924, nr 1-2, s. 16.

44 R., Wyprzedaż zbiorów H. de Backera, „Przegląd Księgarski” 1926, nr 20, s. 393.

4570.000 franków za książkę, „Przegląd Księgarski” 1937, nr 13, s. 128.

46 Hojny dar magnata amerykańskiego, „Przegląd Księgarski” 1922, nr 6-9, s. 130-131.

47 [Biblioteka inż. Józefa Tuleja, Lwów], „Przegląd Księgarski” 1924, nr 1-2, s. 15.

48 Biblioteka Morgana, „Przegląd Księgarski” 1924, nr 3, s. 40-41.

49 (s)., Biblioteki dzieł o wojnie światowej, ,Przegląd Księgarski” 1928, nr 38, s. 610.

50 Ważne odkrycie historyczne, „Przegląd Księgarski” 1925, nr 21, s. 549-550.

51 Zamknięcie bibliotek prywatnych w Rosji, „Przegląd Księgarski” 1925, nr 17, s. 456.

52 R., Wielcy bibliofile angielscy, „Przegląd Księgarski” 1926, nr 17, s. 324-326.

53 R., Wyprzedaż biblioteki p. A. Mounier, „Przegląd Księgarski” 1926, nr 19, s. 370.

54 R., Zabytki biblioteki Napoleona, „Przegląd Księgarski” 1926, nr 22-23, s. 463; M.R., Księgozbiory Napoleona, „Przegląd Księgarski” 1927, nr 15-16, s. 362-363.

55 J. Vorzimmer, Zawód księgarski i społeczeństwo, cz. 3. Obojętność społeczeństwa wobec książki i konieczność przeciwdziałania, „Przegląd Księgarski” 1926, nr 11-12, s. 232-237.

56 Ibidem, s. 234.

57 W.R., O książkach i z powodu książek, „Przegląd Księgarski” 1925, nr 1, s. 10-12.

58 Ibidem, s. 10. 
niedoskonałego świata jest rozkosz, która się nazywa mała biblioteka domowa. Nie zazna tej rozkoszy głupiec, albowiem mu nie przystoi"59.

Księgarze interesowali się także bibliotekami ruchomymi (wędrownymi). Zajmowano się na łamach pisma bibliotekami ruchomymi za granicą, w tym dysponującymi książką polską, na przykład w Brazylii ${ }^{60}$. Przedstawiono początki tego typu bibliotek w Ameryce, które powstały w 1809 roku w celu uzdrowienia sytuacji i poprawy dostępności książki na prowincji (omówiono między innymi komplety, koszty, lokal, problem doboru kompletów) ${ }^{61}$. Ciekawostką może być opis latającej biblioteki dla mieszkańców wysp Wake i Midway na Morzu Południowym, którzy wykorzystywali samoloty także w celu dostarczania im książek $^{62}$, oraz powstanie w Stanach Zjednoczonych stowarzyszenia mającego na celu dostarczanie książek marynarzom na okrętach handlowych ${ }^{63}$. W wypadku polskich bibliotek opisano między innymi ruchomą bibliotekę kolejową na Górnym Śląsku, apelując jednocześnie do pozostałych dyrekcji kolejowych o uruchomienie następnych ${ }^{64}$. Podjęto także problematykę powiatowych centrali bibliotecznych ${ }^{65}$.

Biblioteki publiczne równie żywo zajmowały księgarstwo. Polscy księgarze mogli przeczytać w swoim piśmie o bibliotekach publicznych w: Stanach Zjednoczonych $^{66}$, Czechosłowacji ${ }^{67}$, Niemczech ${ }^{68}$, Rosji, Anglii, Japonii ${ }^{69}$. Szczegółowa tematyka to: historia placówek, statystyki, sponsorzy, dary, propaganda (między innymi współpraca księgarstwa z bibliotekami publicznymi, konkursy), formy udostępniania (między innymi fotograficzne odbitki stron książek ${ }^{70}$ ), cenzura ${ }^{71}$, książka polska w zagranicznych bibliotekach ${ }^{72}$, biblioteki publiczne ze zbiorami dla niewidomych ${ }^{73}$. W 1939 roku pojawiły się także doniesienia o akcjach palenia

59 Ibidem, s. 12.

60 Wystawa książki polskiej w Kurytybie, „Przegląd Księgarski” 1928, nr 20, s. 318.

61 L. Ro-n, Biblioteczki ruchome. Pomysłowość samorządów amerykańskich w dziedzinie czytelnictwa, „Przegląd Księgarski” 1928, nr 43, s. 686-688.

62 Latająca wypożyczalnia książek, „Przegląd Księgarski” 1937, nr 1-2, s. 10.

63 Biblioteka dla marynarzy, „Przegląd Księgarski” 1928, nr 21, s. 331.

64 Ruchoma biblioteka kolejowa na Górnym Śląsku, „Przegląd Księgarski” 1928, nr 45, s. 723.

65 Ruchome biblioteki w walizkach, „Przegląd Księgarski” 1936, nr 22, s. 201.

66 Biblioteka nowojorska, „Przegląd Księgarski” 1923, nr 6, s. 87; Propaganda książki w Ameryce, „Przegląd Księgarski” 1925, nr 23-24, s. 601-604; Konkurs na najgorsza książkę, „Przegląd Księgarski” 1926, nr 8, s. 186; J. Raczkowski, Sprawozdanie z działalności Biblioteki Publicznej w New-Yorku, za rok 1925. (The New-York Public Library), „Przegląd Księgarski” 1926, nr 21, s. 426-427.

67 Rozrost bibliotek publicznych w Czecho-Stowacji, „Przegląd Księgarski” 1926, nr 1, s. 19.

68 Najstarszy exlibris miejski, „Przegląd Księgarski” 1926, nr 2, s. 38-39.

69 Księgarstwo w Japonii, „Przegląd Księgarski” 1938, nr 1-2, s. 10-11.

70 Fotostat, „Przegląd Księgarski” 1925, nr 22, s. 571.

71 Bolszewickie barbarzyństwo, „Przegląd Księgarski” 1928, nr 11, s. 175.

72 Jak Polacy czytają książki polskie, ,Przegląd Księgarski” 1926, nr 15-16, s. 292-293.

73 Niezwykła biblioteka dla niewidomych, „Przegląd Księgarski” 1936, nr 3-4, s. 29-30. 
książek w Kłajpedzie przez niemiecką policję polityczną i grupę szturmowców hitlerowskich ${ }^{74}$.

W wypadku polskich bibliotek publicznych omówione zostały między innymi placówki w Warszawie ${ }^{75}$, Toruniu ${ }^{76}$, Zamościu ${ }^{77}$, Inowrocławiu ${ }^{78}$, Lodzi $^{79}$. Analizowane teksty zawierały: sprawozdania z uroczystości otwarcia bibliotek lub tylko informacje o ich uruchomieniu, opis organizacji i zarządzania placówkami, wzmianki o jubileuszach książnic, stan czytelnictwa. Na uwagę zasługują teksty poruszające związki między światem księgarskim a bibliotekami publicznymi, między innymi opublikowana w 1924 roku informacja o powstaniu Towarzystwa Bibliotek Publicznych z połączenia bibliotek warszawskich i apel do wydawców o nadsyłanie do Towarzystwa egzemplarzy recenzyjnych dla komisji zakupów ${ }^{80}$. Księgarze byli także fundatorami bibliotek publicznych ${ }^{81}$.

Cytowany już J. Vorzimmer zwrócił w swoim artykule uwagę na sytuację związaną z zakładaniem bibliotek w Polsce. W okresie zaborów było to utrudnione, ale jego zdaniem niewiele zmieniło się po odzyskaniu niepodległości. W innych krajach, na przykład Ameryce, biblioteki tworzono w każdym mieście. Fundatorami byli na ogół obywatele, a biblioteka nosiła imię darczyńcy. Autor opisał gęstą sieć bibliotek publicznych w Stanach Zjednoczonych, w kontrze ukazując polskie realia - małą liczbę bibliotek, rzadko występujących fundatorów bibliotek publicznych: „Czyż istotnie nie ma już w Polsce Stasziców, a są tylko bogacze, zapisujący majątki na pielęgnowanie swoich koni?..."82

Biblioteki uczelniane nie były zbyt częstym tematem rozważań na łamach księgarskiego pisma. Placówki polskie pojawiły się w kontekście: egzemplarza obowiązkowego ${ }^{83}$, próśb o dary do zbiorów i podziękowań za dotychczasową pomoc $^{84}$, warunków lokalowych, zbiorów ${ }^{85}$. Teksty dotyczące bibliotek uczelni

74 Palenie książek w Ktajpedzie, „Przegląd Księgarski” 1939, nr 16, s. 202.

75 Biblioteka Publiczna, „Przegląd Księgarski” 1925, nr 20, s. 524; Sprawa Biblioteki Publicznej w Warszawie, „Przegląd Księgarski” 1928, nr 6, s. 94.

76 [Książnica Miejska im. Kopernika w Toruniu], „Przegląd Księgarski” 1923, nr 12, s. 186.

77 Koło Miłośników Książki w Zamościu, „Przegląd Księgarski” 1927, nr 29, s. 603-604.

78 Biblioteka Publiczna w Inowrocławiu, „Przegląd Księgarski” 1928, nr 6, s. 94.

79 Biblioteka Publiczna w Łodzi, „Przegląd Księgarski” 1928, nr 9, s. 142.

80 Ku uwadze wydawców, „Przegląd Księgarski” 1924, nr 6-7, s. 111.

81 Ofiarność księgarska, „Przegląd Księgarski” 1926, nr 17, s. 322; Podziękowanie, „Przegląd Księgarski” 1928, nr 52, s. 912.

82 J. Vorzimmer, op. cit., s. 233.

83 Egzemplarze obowiązowe dla Biblioteki Lwowskiej i Poznańskiej, „Przegląd Księgarski" 1920, nr 1-2, s. 10.

84 O książki dla polonistów, „Przegląd Księgarski” 1923, nr 12, s. 188-189.

85 [Biblioteka Jagiellońska], „Przegląd Księgarski” 1927, nr 7, s. 182-183; Biblioteka uniwersytecka, „Przegląd Księgarski” 1928, nr 7, s. 109. 


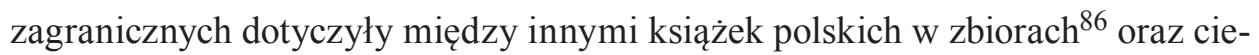
kawych kolekcji 87 .

Tematyka zagranicznych bibliotek naukowych dotyczyła: dziejów placówek, zbiorów, zasad korzystania. Reprezentowane były między innymi Biblioteka Niemieckiego Instytutu Archeologicznego w Rzymie ${ }^{88}$, biblioteka w Tebach ${ }^{89}$. W wypadku polskich bibliotek naukowych na uwagę zasługuje odnotowanie obchodów setnej rocznicy otwarcia zbiorów dla czytelników Zakładu Narodowego im. Ossolińskich ${ }^{90}$.

Ważnym tematem dla księgarzy były biblioteki fachowe, w tym tworzenie biblioteki przy ZKP. Było to spowodowane koniecznością dokształcania się w zawodzie, a także kształcenia młodych kadr. Kwestia założenia biblioteki związkowej pojawiła się już w roczniku 1918/1919 ${ }^{91}$. Opisywano książki, które powinny znaleźć się w biblioteczce fachowej księgarza ${ }^{92}$. W 1928 roku omówiono bibliotekę zawodową Związku, która powstała z daru Ludwika Fiszera i zakupów. Sporządzono prowizoryczny spis zbiorów, który wysyłano na życzenie do zarejestrowanych firm. Książki z biblioteki związkowej można było bezpłatnie wypożyczać — „W ogólnym interesie księgarstwa leży, by korzystanie z biblioteki przybrało jak największe rozmiary"93. W kolejnych numerach informowano księgarzy o nabytkach biblioteki. W 1936 roku na łamach „Przeglądu Księgarskiego" pojawiła się informacja o inicjatywie ZG ZKP utworzenia biblioteki wiedzy o książce przy Związku. Opublikowano apel do wydawców, by nadsyłali bezpłatnie wszystkie nowości z tej dziedziny, a starsze rzeczy przekazywali w darze lub sprzedali za możliwie niską cenę. Na każdej książce miała być umieszczona data, imię i nazwisko ofiarodawcy ${ }^{94}$. Podejmowano także problematykę bibliotek dla innych grup zawodowych, między innymi robotników ${ }^{95}$, marynarzy ${ }^{96}$, literatów

86 Dziat polski w bibliotece uniwersyteckiej w Białogrodzie, „Przegląd Księgarski” 1925, nr 21, s. 549; Ksią̇ki polskie w Bibliotece Uniwersyteckiej we Fryburgu, „Przegląd Księgarski” 1927, nr 29, s. 604-605.

87 Zbiór mszałów rękopiśmiennych w Bibliotece Uniwersytetu Helsingforskiego, „Przegląd Księgarski” 1925, nr 1, s. 18; (s)., Biblioteki dzieł o wojnie światowej..., s. 610.

88 Bezdomna biblioteka, „Przegląd Księgarski” 1922, nr 3, s. 67.

89 Biblioteka dla egiptologów, „Przegląd Księgarski” 1927, nr 8-9, s. 228.

90 Stulecie Ossolineum, „Przegląd Księgarski” 1928, nr 11, s. 173; Uroczystości jubileuszowe „Ossolineum”, „Przegląd Księgarski” 1928, nr 23, s. 356-357.

91 Zwiazek Księgarzy Polskich, „Przegląd Księgarski” 1918/1919, nr 1, s. $24-25$.

92 Do Biblioteki Zawodowej, „Przegląd Księgarski” 1927, nr 18, s. 400-401; Do biblioteki księgarza, „Przegląd Księgarski” 1928, nr 50, s. 873.

93 Biblioteka Zawodowa Związku, „Przegląd Księgarski” 1928, nr 43, s. 678.

94 Biblioteka wiedzy o książce, „Przegląd Księgarski” 1936, nr 2, s. 11.

95 Miesiąc propagandy książki, „Przegląd Księgarski” 1927, nr 26, s. 535; Powodzenie literatury pornograficznej w Rosji Sowieckiej, „Przegląd Księgarski” 1928, nr 23, s. 366; Biblioteki dźwigna czytelnictwo, „Przegląd Księgarski” 1928, nr 40, s. 641.

96 Biblioteka dla marynarzy... 
i artystów ${ }^{97}$, żołnierzy ${ }^{98}$. Na łamach pisma pojawiały się również informacje dotyczące bibliotek lekarskich, szpitalnych — głównie w kontekście podziękowania za przekazane dary ${ }^{99}$.

Zwracano uwagę księgarzy na liczne w okresie dwudziestolecia międzywojennego biblioteki parafialne ${ }^{100}$. W 1936 roku Adam Szymański informował o akcji zakładania bibliotek parafialnych i szpitalnych. Apelowano do księgarzy o wykorzystanie okazji, ponieważ biblioteki dokonywały zakupu głównie w księgarniach sortymentowych ${ }^{101}$. Podobny wydźwięk miał tekst z 1938 roku, w którym informowano o synodzie polskim, który odbył się w Częstochowie, i podjętej tam uchwale dotyczącej pism i wydawnictw katolickich. Redakcja apelowała do księgarzy, by w związku z zaistniałą sytuacją postarali się o odpowiedni asortyment w swoich księgarniach, a może nawet o prowadzenie kiosku przy kościele ${ }^{102}$.

Na łamach „Przeglądu Księgarskiego” można znaleźć także informacje o zagranicznych bibliotekach o charakterze religijnym, między innymi Bibliotece Żydowskiego Seminarium Teologicznego w Nowym Jorku ${ }^{103}$, Bibliotece Watykańskiej ${ }^{104}$, bibliotekach kościelnych w Stanach Zjednoczonych ${ }^{105}$.

Księgarze zainteresowani byli również bibliotekami organizowanymi przy różnych instytucjach, takich jak sejm i senat ${ }^{106}$, muzea ${ }^{107}$, pałace ${ }^{108}$, szkoła księgarska $^{109}$. Warto w tym wypadku wspomnieć o biblioteczkach podręcznych dla urzędów gminnych. W „Przeglądzie Księgarskim” apelowano, głównie do księgarzy na prowincji, o zainteresowanie się tą sprawą i wykorzystanie faktu, że urzędy zobowiązane były do posiadania bibliotek podręcznych, na które przeznaczone zo-

97 Polskie Towarzystwo Ochrony Prawa Autorskiego, „Przegląd Księgarski” 1936, nr 15, s. 140 .

98 O książki dla żotnierzy, „Przegląd Księgarski” 1923, nr 12, s. 187; Podziękowanie czytelni żotnierskich, „Przegląd Księgarski” 1926, nr 3, s. 53.

99 [Zalewska Waleria], „Przegląd Księgarski” 1923, nr 6, s. 82.

100 Biblioteki parafialne, „Przegląd Księgarski” 1935, nr 19, s. 112.

101 (als.), Baczność księgarze!, „Przegląd Księgarski” 1936, nr 12, s. 105.

102 Uchwaty Synodu Polskiego o pismach $i$ wydawnictwach, „Przegląd Księgarski” 1938, nr 1-2, s. 13.

103 Największa biblioteka żydowska, „Przegląd Księgarski” 1924, nr 1-2, s. 16.

104 Ciekawe odkrycie w Bibliotece Watykanu, „Przegląd Księgarski” 1928, nr 14, s. 223; Katalogowanie Biblioteki Watykańskiej, „Przegląd Księgarski” 1928, nr 38, s. 609.

105 Osobliwości amerykańskiego rynku księgarskiego, „Przegląd Księgarski” 1928, nr 27, s. 431.

106 Biblioteka Sejmu i Senatu, „Przegląd Księgarski” 1926, nr 15-16, s. 296.

107 Nowa biblioteka w Warszawie, ,Przegląd Księgarski” 1925, nr 19, s. 505-506; Największa biblioteka dzieł z historii sztuki, „Przegląd Księgarski” 1926, nr 22-23, s. 464.

108 R., Wyprzedaż materiałów i rękopisów z XIII-go i XIV-go wieku, należacych do biblioteki zamku de la Roche-Guyon, „Przegląd Księgarski” 1927, nr 20, s. 443-444; St.Pl., Dzików ostrzeżeniem i doskonała okazją, „Przegląd Księgarski” 1928, nr 5, s. 76-77.

109 (F.B.), Szkoła księgarska, „Przegląd Księgarski” 1937, nr 9, s. 92. 
stały konkretne fundusze ${ }^{110}$. W odniesieniu do bibliotek społecznych, należących do różnych organizacji, warto zwrócić uwagę na teksty omawiające inicjatywy księgarzy wspomagające tworzenie tych bibliotek (przykłady firm: M. Arct, Gebethner i Wolff) ${ }^{111}$, informowanie o specjalnych ofertach ${ }^{112}$.

W wypadku bibliotek dla dzieci opisywano ich działalność, organizację, warunki lokalowe, czytelników. Kilka tekstów poświęcono Bibliotece Wzorowej dla Dzieci i Młodzieży ofiarowanej przez ZKP i wydawców po Wystawie Książki Polskiej. Pozostałe teksty dotyczyły Warszawy ${ }^{113}$ i Łodzi ${ }^{114}$.

Biblioteki organizowane na wsiach nie zaprzątały szczególnej uwagi środowiska księgarskiego. W 1925 roku przedrukowano na ten temat artykuł z „Gazety Ludowej”115, a w 1928 roku z „Kuriera Warszawskiego"116. Informowano o dotacjach ministerialnych dla bibliotek ${ }^{117}$ lub o lokalnych inicjatywach środowiska wiejskiego (na przykład w 1939 roku zawiadamiano, że Powiatowa Organizacja Kół Gospodyń Wiejskich w Piotrkowie wszczęła akcję biblioteczną w celu samokształcenia i miała zakładać biblioteki — apel do tamtejszych księgarzy o zainteresowanie się sprawą) $)^{118}$.

Temat egzemplarza obowiązkowego rzadko pojawiał się na łamach „Przeglądu Księgarskiego”. W roczniku 1918/1919 zamieszczono apel do wydawców, by mimo braku rozporządzenia przesyłać egzemplarz obowiązkowy do bibliotek ${ }^{119}$. Inne poruszane aspekty to: postulat drukowania egzemplarza obowiązkowego na trwalszym papierze ${ }^{120}$, kwestia przechowywania egzemplarza obowiązkowego w bibliotekach ${ }^{121}$.

Największa liczba analizowanych tekstów dotyczyła ogólnych spraw bibliotecznych. W wypadku bibliotekarstwa zagranicznego były to: cenzura i usuwa-

110 Baczność sortymentyści! Biblioteki podręczne urzędów gminnych, „Przegląd Księgarski" 1939 , nr 2, s. 11.

111 Ofiarność księgarni M. Arcta, „Przegląd Księgarski” 1918/1919, nr 6, s. 158; Poświęcenie filii paryskiej „,Gebethnera i Wolffa”, „Przegląd Księgarski” 1925, nr 15-16, s. 425.

112 [Księgarnia „Kroniki Rodzinnej”, Warszawa], „Przegląd Księgarski” 1918/1919, nr 3, s. 95.

113 Biblioteka dziecięca, „Przegląd Księgarski” 1926, nr 13-14, s. 269-270; Wystawa wzorowej biblioteki dla dzieci i młodzieży, „Przegląd Księgarski” 1926, nr 21, s. 418-419; Wystawa biblioteki wzorowej dla dzieci i młodzieży, „Przegląd Księgarski” 1927, nr 7, s. 188; Otwarcie wzorowej biblioteki dla dzieci, „Przegląd Księgarski” 1928, nr 5, s. 78; Sprawozdanie Biblioteki Wzorowej dla dzieci. Dar Związku Księgarzy Polskich, „Przegląd Księgarski” 1928, nr 44, s. 702-704.

114 Co czytają dzieci, „Przegląd Księgarski” 1926, nr 18, s. 34; Czytelnictwo wśród młodzieży tódzkiej, „Przegląd Księgarski” 1927, nr 30, s. 619.

115 O biblioteki dla wsi, „Przegląd Księgarski” 1925, nr 4, s. 113-114.

116 Głód duchowy na wsi, „Przegląd Księgarski” 1927, nr 20, s. 440-441.

11720 tysięcy na biblioteki wiejskie, „Przegląd Księgarski” 1939, nr 1, s. 5.

118 Baczność! Księgarze piotrkowscy, „Przegląd Księgarski” 1939, nr 20, s. 249-250.

119 [Egzemplarz obowiązkowy], „Przegląd Księgarski” 1918/1919, nr 3, s. 89.

120 Ratujmy biblioteki od zagłady!, „Przegląd Księgarski” 1923, nr 12, s. 184-185.

121 Biblioteki polskie przeciążone balastem ksiażek bezwartościowych, nadsyłanych przez drukarnie w myśl nowej ustawy prasowej, „Przegląd Księgarski” 1927, nr 21, s. 459-460. 
nie dzieł z bibliotek (Rosja ${ }^{122}$, Niemcy ${ }^{123}$ ), budżety bibliotek (Francja) ${ }^{124}$, prawo autorskie a udostępnianie ${ }^{125}$, kwestie techniczne związane z przechowywaniem i udostępnianiem czasopism (Stany Zjednoczone) ${ }^{126}$, udostępnianie ${ }^{127}$. Tematyka dotycząca bibliotekarstwa polskiego: groźba zamykania bibliotek ze względu na brak funduszy (Warszawa) ${ }^{128}$, przewodnik po bibliotekach warszawskich (zawartość, cena) ${ }^{129}$, higiena książek ${ }^{130}$, zamykanie czytelni ze względu na zły stan sanitarny ${ }^{131}$, zmiany w rejestrze dotyczące wypożyczalni i czytelni przy księgarniach, dane statystyczne ${ }^{132}$, opłaty pocztowe ${ }^{133}$, gromadzenie $^{134}$ i spekulacje handlarzy ${ }^{135}$, wypożyczalnie przy księgarniach sortymentowych ${ }^{136}$.

Ważny temat z punktu widzenia księgarstwa poruszono między innymi w 1928 roku. Była to kwestia licznych próśb o książki do nowo powstających bibliotek różnego typu. Określano to zjawisko mianem tzw. żebraniny książkowej, czyli prośby do wydawców i księgarzy o darmowe książki. Nie było to tylko polskie zjawisko. Podkreślano, że księgarze już pomagali bibliotekom, na przykład duże organizacje i biblioteki szkolne otrzymywały większe rabaty. Przyczyną próśb mogło być przyzwyczajenie z okresu zaborów, kiedy księgarze rozdawali książki jako narzędzie zachowania polskości. W niepodległej Polsce obowiązywały już jednak zasady gospodarki rynkowej, był rząd, władza państwowa, które

122 Cenzurowanie książek w Rosji, „Przegląd Księgarski” 1924, nr 6-7, s. 115; Na indeksie bolszewickim, „Przegląd Księgarski” 1924, nr 4-5, s. 75; ,, Szkodliwe” książki, „Przegląd Księgarski” 1925, nr 10, s. 322.

123 „Konrad Wallenrod” Mickiewicza na niemieckim indeksie, „Przegląd Księgarski” 1936, nr 18, s. 171.

124 Budżet bibliotek francuskich, „Przegląd Księgarski” 1925, nr 13-14, s. 394-395.

125 W.K., Czytelnie a pisarze. (Paradoksalna sytuacja), „Przegląd Księgarski” 1926, nr 24, s. 497; Jak czytelnie (wypożyczalnie książek) oddziatywują na sprzedaż ksiązek, „Przegląd Księgarski" 1926, nr 15-16, s. 286-287. Temat obecny również w odniesieniu do Polski: J. Lesman, Wypożyczanie książek wobec prawa autorskiego, „Przegląd Księgarski” 1936, nr 13, s. 110-111; Autor powieści przeciwko czytelni, ,Przegląd Księgarski” 1936, nr 15, s. 1.

126 W trosce o przyszłość, „Przegląd Księgarski” 1927, nr 4, s. 98.

127 Święto zwrotu pożyczonych książek, „Przegląd Księgarski” 1928, nr 13, s. 202.

128 Co mówią i pisza o kryzysie księgarskim, „Przegląd Księgarski” 1924, nr 9-10, s. 156-161.

129 Przewodnik po bibliotekach warszawskich, „Przegląd Księgarski” 1926, nr 8, s. 185.

130 Higiena książek, „Przegląd Księgarski” 1927, nr 18, s. 409-410.

131 Zamknięcie siedmiu czytelni w Warszawie, „Przegląd Księgarski” 1936, nr 7, s. 54.

1327.968 .800 tomów w bibliotekach polskich. 451 bibliotek na obszarze Rzeczypospolitej, „Przegląd Księgarski” 1928, nr 9, s. 141; Rejestracja bibliotek publicznych i ogólnokształcacych, „Przegląd Księgarski” 1931, nr 4, s. 41-42.

133 Zwolnienie od opłat pocztowych druków, dostarczanych dla celów bibliotecznych i dla urzędowej rejestracji, „Przegląd Księgarski” 1928, nr 36, s. 576-577.

134 Walski, Jeszcze w sprawie rabatowania publiczności, „Przegląd Księgarski” 1939, nr 20, s. 246.

135 Znalazt się mądrala, „Przegląd Księgarski” 1938, nr 1-2, s. 10.

136 Kącik czytelniarzy, „Przegląd Księgarski” 1938, nr 7, s. 58-59; Rejestracja wypożyczalni, „Przegląd Księgarski” 1939, nr 17-18, s. 223. 
powinny się tym zająć. Księgarze natomiast po prostu musieli zarabiać na życie ${ }^{137}$. Inną ważną dla księgarzy kwestią był import książek z pominięciem księgarzy ${ }^{138}$. Problemem było także udzielanie dużych rabatów przez wydawców dla bibliotek i czytelni. Powodowało to odpływ klientów z księgarni sortymentowych, a tym samym mniejsze wpływy ${ }^{139}$.

Księgarze domagali się uczestnictwa w tworzeniu prawa dotyczącego egzemplarzy obowiązkowych, bibliotek, praw autorskich — podając za przykład Francję, Anglię i Niemcy. Ustawa biblioteczna była tematem bardzo popularnym w prasie dwudziestolecia międzywojennego. W „Przeglądzie Księgarskim” także pojawiły się tego typu teksty. Przedstawiano ustawy funkcjonujące w innych krajach i ich najważniejsze punkty, odnosząc się do realiów polskich oraz prac nad poszczególnymi projektami. Głos na łamach omawianego pisma zabrali: Wanda Dąbrowska $^{140}$, Jadwiga Filipkowska-Szemplińska ${ }^{141}$, Jan Muszkowski ${ }^{142}$. Informowano o korzyściach uchwalenia ustawy dla polskiego bibliotekarstwa. Pojawiały się sprawozdania z prac komisji, komitetów i organizacji zajmujących się przygotowywaniem ustawy. Przedrukowywano ciekawe wypowiedzi pojawiające się na łamach ogólnopolskiej prasy.

Księgarze interesowali się także sprawami bibliotekarzy jako grupy zawodowej i ich obowiązkami. Do tematów szczegółowych można zaliczyć: kształcenie $^{143}$, organizacje, instytucje i zjazdy bibliotekarskie oraz czasopisma dla bibliotekarzy.

Analiza zawartości „Przeglądu Księgarskiego” wykazała, że środowisko księgarskie było zainteresowane sprawami związanymi z bibliotekarstwem. Redakcja pisma starała się informować ogół księgarstwa polskiego o wszystkich najważniejszych kwestiach dotyczących bibliotek i bibliotekarzy. Placówki biblioteczne były odbiorcą dużej liczby asortymentu księgarskiego. Z drugiej jednak strony występował konflikt interesów, ponieważ książka zakupiona do biblioteki, wypożyczalni czy czytelni mogła być przeczytana przez wiele osób, co mogło wpłynąć

137 St.K., Nie wstydźmy się zarabiać, „Przegląd Księgarski” 1928, nr 19, s. 290-292.

138 W sprawie importu książki zagranicznej, „Przegląd Księgarski” 1936, nr 10, s. 84-85; I. Gir-ski, O zamówieniach na wydawnictwa zagraniczne, „Przegląd Księgarski” 1930, nr 26, s. $361-362$.

139 S. Kowalewski, Zagadnienie czytelniano-biblioteczne a interesy wydawcy i sortymentysty. (Referat wygłoszony na zebraniu Koła warszawskiego ZKP dnia 28.IV.1938 r.), „Przegląd Księgarski” 1938, nr 10, s. 102, 104, 106; Rabat księgarski tylko dla księgarza, „Przegląd Księgarski” 1939, nr 3, s. 18.

140 W. Dąbrowska, Ustawodawstwo biblioteczne i jego wartość życiowa, „Przegląd Księgarski" 1927, nr 4, s. 77-86.

141 J. Filipkowska-Szemplińska, Wpływ ustawy o bibliotekach publicznych w Czechostowacji na rynek księgarski, „Przegląd Księgarski” 1928, nr 16, s. 245-248.

142 J. Muszkowski, W sprawie organizacji wytwarzania i obiegu ksiązki. (Dokończenie), „Przegląd Księgarski” 1927, nr 25, s. 519-520.

${ }_{143}$ Kurs bibliotekarski, „Przegląd Księgarski” 1922, nr 12, s. 185-186; Kursy bibliotekarskie, „Przegląd Księgarski” 1939, nr 20, s. 250. 
na zmniejszenie liczby klientów księgarń sortymentowych. Księgarze mieli jednak świadomość, że rozbudzona przez biblioteki potrzeba czytania może przyczynić się do chęci gromadzenia prywatnego księgozbioru, dlatego też uczestniczyli w akcjach propagujących czytelnictwo, szczególnie na terenie szkoły, włączali się do dyskusji nad ustawą biblioteczną w Polsce i apelowali o dofinansowanie bibliotek z funduszy odpowiednich ministerstw.

Teksty o bibliotekach były bardzo pomocne w planowaniu pracy i działalności propagandowej księgarń. Informacje podane w „Przeglądzie Księgarskim” umiejętnie wykorzystane - mogły przynieść wymierne efekty. Wzmianki o bibliotekach zagranicznych — ich funkcjonowaniu, zasadach organizacji, sposobach zarządzania, nowościach w udostępnianiu - dawały możliwość przeniesienia pewnych rozwiązań na grunt polski, czerpania z doświadczeń w kwestii współpracy księgarstwa zagranicznego z placówkami bibliotecznymi.

„Przegląd Księgarski” jako czasopismo fachowe spełnił swoją rolę w kwestii informowania środowiska księgarskiego o polskim i zagranicznym bibliotekarstwie. Umiejętnie ukierunkowywał działania księgarzy, które przekładały się na poprawę sytuacji materialnej polskich placówek księgarskich, ale także na rozwój czytelnictwa.

\section{Bibliografia (wybór)}

„Przegląd Księgarski” 1918/1919, nr 1-14/15; 1920, nr 1-2; 1922, nr 1-12; 1923, nr 1/2-12; 1924, nr 1/2-12; 1925, nr 1-23/24; 1926, nr 1-24; 1927, nr 1-30; 1928, nr 1-53; 1935, nr 1-24; 1936, nr 1-24; 1937, nr 1/2-21; 1938, nr 1/2-24; 1939, nr 1-22/23.

(als.), Baczność księgarze!, „Przegląd Księgarski” 1936, nr 12, s. 105.

Baczność! Księgarze piotrkowscy, „Przegląd Księgarski” 1939, nr 20, s. 249-250.

Baczność sortymentyści! Biblioteki podręczne urzędów gminnych, „Przegląd Księgarski” 1939, nr 2, s. 11.

Biblioteka dla marynarzy, „Przegląd Księgarski” 1928, nr 21, s. 331.

Biblioteka Szkolna im. Michała Arcta przy PMS, „Przegląd Księgarski” 1918/1919, nr 2, s. 62.

Biblioteka wiedzy o książce, „Przegląd Księgarski” 1936, nr 2, s. 11.

Biblioteka Zawodowa Związku, „Przegląd Księgarski” 1928, nr 43, s. 678.

Czy nowy monopol?, „Przegląd Księgarski” 1925, nr 1, s. 9-10.

Echa „Miesiąca Ksiązki”, „Przegląd Księgarski” 1927, nr 6, s. 132.

Echa „, Miesiąca książki”. Sejmik Hrubieszowski, „Przegląd Księgarski” 1927, nr 4, s. 75.

[Egzemplarz obowiązkowy], „Przegląd Księgarski” 1918/1919, nr 3, s. 89.

Hojny dar, „Przegląd Księgarski” 1922, nr 4 i 5, s. 98.

Kowalczyk S., Nowy podatek, „Przegląd Księgarski” 1928, nr 6, s. 88-90.

L. Ro-n, Biblioteczki ruchome. Pomysłowość samorządów amerykańskich $w$ dziedzinie czytelnictwa, „Przegląd Księgarski” 1928, nr 43, s. 686-688.

Latająca wypożyczalnia książek, „Przegląd Księgarski” 1937, nr 1-2, s. 10.

Memoriał Związku Polskich Księgarzy Wydawców, złożony dn. 23 lutego 1926 r. Sejmowi w sprawie bibliotek szkolnych, „Przegląd Księgarski” 1926, nr 4-5, s. 85-86. 
Miesiąc książki dla młodzieży szkót powszechnych, „Przegląd Księgarski” 1927, nr 1, s. 3-7.

Miesiąc ksiązki dla młodzieży szkót powszechnych, „Przegląd Księgarski” 1927, nr 2, s. 32-33.

Nasza danina, „Przegląd Księgarski” 1927, nr 3, s. 64-65.

Olczak-Kardas M., ,,Przeglad Księgarski”. Adnotowana bibliografia zawartości za lata 1918-1939, t. 1. 1918-1925, Kielce 2016; t. 2. 1926-1928, Kielce 2017.

Palenie ksiązek w Kłajpedzie, „Przegląd Księgarski” 1939, nr 16, s. 202.

Ruchoma biblioteka kolejowa na Górnym Ślasku, „Przegląd Księgarski” 1928, nr 45, s. 723.

Salinger R., ,Przegląd Księgarski” w latach 1918-1939, „Księgarz” 1971, nr 3, s. 44-54.

St.K., Nie wstydźmy się zarabiać, „Przegląd Księgarski” 1928, nr 19, s. 290-292.

St.Pl., W sprawie Biblioteki Narodowej, „Przegląd Księgarski” 1928, nr 14, s. 213-215.

Szkolne biblioteki dla młodzieży, „Przegląd Księgarski” 1927, nr 1, s. 20.

[Towarzystwo Opieki Kulturalnej nad Polakami Zamieszkałymi Zagranicą im. A. Mickiewicza], „Przegląd Księgarski” 1923, nr 12, s. 182-183.

Uchwały Synodu Polskiego o pismach $i$ wydawnictwach, „Przegląd Księgarski” 1938, nr 1-2, s. 13.

Vorzimmer J., Zawód księgarski i społeczeństwo, cz. 3. Obojętność społeczeństwa wobec książi i konieczność przeciwdziałania, „Przegląd Księgarski” 1926, nr 11-12, s. 232-237.

W.R., O książkach i z powodu ksiązek, „Przegląd Księgarski” 1925, nr 1, s. 10-12.

Wyjaśnienie, „Przegląd Księgarski” 1925, nr 3, s. 75.

\title{
Libraries of the interwar period on the pages of Przegląd Księgarski
}

\begin{abstract}
Summary
The article depicts libraries and their functions in the interwar period as presented in Przeglad Ksiegarski, a paper which was the press organ of the Union of Polish Booksellers. The research has been limited to the 1918/1919-1920, 1922-1928 and 1935-1939 years' issues. A total of 381 papers on library issues have been analyzed. The vast majority of the content was connected with Polish libraries. The articles primarily echoed bookselling-related developments in the Polish librarianship. As regards the foreign libraries, the papers mainly discussed private and public libraries, and library acts. The research has revealed a wide range of the topics addressed. Those, inter alia, involved statistical data pertaining to collections of books and readers, functions and tasks of the libraries of different types, library organization and basic procedures with special reference to the library collections policy. The articles also dealt with such major issues as the idea of the national library, legal deposit and the legal basis for library services. The reader could also find some information on union activity of the librarians, vocational training programmes and library press.
\end{abstract}

KEYWORDS: Bookselling Review, professional journals, librarianship, Second Polish Republic 